23 Nopember 2015

11:50

nurul Page 1 


\title{
SIKLUS MENSTRUASI PADA MAHASISWI YANG MENGALAMI STRES DI STIKES YARSIS
}

\author{
Nurul Kamariyah \\ (Stikes Yarsis, Jl. Smea 57 Surabaya) \\ email: kamariyahnurul@ymail.com
}

\begin{abstract}
Abstrak: One characteristic of the young woman is menstruating. Menstruation is often accompanied by physical and mental disorders. Knowing the characteristics of menstruation, menstrual disorders and their relationship to the activity, as well as efforts to reduce menstrual disorders. The type of study is analytic with method of Cross Sectional Study, using questionnaires to 185 female students STIKes YARSIS in November 2009. The result $92.1 \%$ of respondents menarche at age $10-14.90 \%$ of respondents have a longer period for $6-9$ days, and $87.1 \%$ of respondents have a long cycle for $25-32$ days. $81.7 \%$ is a more emotional feeling before menstruation. $89.2 \%$ of respondents experiencing pain in the lower abdomen during menstruation. Correlation levels before menstruation disorders with learning activities significancy worth 0.030 with 0.226 correlation value. $58.4 \%$ of respondents reducing premenstrual disorders with rest and $88.4 \%$ of respondents reduces menstrual complaints by lying. The more weight the menstrual complaints will increasingly affect the learning activities. Resting is considered the most effective measures to reduce noise both before and during menstruation.
\end{abstract}

Keyword: stress, mentruation

\begin{abstract}
Abstrak: Salah satu ciri dari remaja putri adalah mengalami menstruasi. Menstruasi seringkali disertai gangguan fisik dan mental. Tujuan penelitian ini adalah mengetahui karakteristik menstruasi, gangguan menstruasi dan hubungannya dengan aktivitas, serta upaya mengurangi gangguan menstruasi. Metode : Cross Sectional Study, menggunakan kuesioner kepada 185 mahasiswi Stikes Yarsis pada bulan Nopember 2009. Hasil: 92,1\% responden menarche pada usia 10-14. 90\% responden memiliki lama menstruasi selama 69 hari, dan $87,1 \%$ responden memiliki lama siklus selama $25-32$ hari. $81,7 \%$ adalah merasakan lebih emosional menjelang menstruasi. $89,2 \%$ responden mengalami rasa nyeri di bawah perut saat menstruasi. Korelasi tingkat gangguan menjelang menstruasi dengan aktivitas belajar bernilai significancy 0,030 dengan nilai korelasi $0,226.58,4 \%$ responden mengurangi gangguan menjelang menstruasi dengan beristirahat dan $88,4 \%$ responden mengurangi keluhan saat menstruasi dengan berbaring. Kesimpulan pada pernelitian ini adalah semakin berat tingkat keluhan menstruasi akan semakin mempengaruhi aktivitas belajar. Beristirahat merupakan upaya yang dirasa paling efektif untuk mengurangi gangguan baik menjelang maupun saat menstruasi
\end{abstract}

Kata kunci : stres, menstruasi 


\section{PENDAHULUAN}

Dewasa ini telah banyak ilmuwan dan pakar filsafat melakukan penelitian mengenai hubungan antara pikiran/perasaan dan fungsi-fungsi tubuh manusia. Seiring dengan pemahaman akan peran stres dalam kehidupan manusia, maka telah pula ditemukan gangguan psiko-fisiologis, yang merupakan manifestasi gangguan fisik seseorang akibat stres yang dialaminya. Penelitian Jeffcoate menyatakan kira-kira $20 \%$ diantara para wanita tidak mengalami gangguan apapun, karena peristiwa menstruasi ditentukan oleh proses somato-psikis yang sifatnya kompleks meliputi unsurunsur hormonal, biokimiawi, dan psikososial, serta sering disertai gangguan fisik dan mental (Wiknjosastro, 2005). Data penelitian sebelumnya (Rubianti 2006) dikatakan bahwa mahasiswa yang mengalami stress berat akan berpengaruh kepada proses pembelajaran dan siklus mentruasi sampai $70 \%$.

Panjang siklus haid rata-rata pada gadis usia 12 tahun ialah 25,1 hari, pada wanita usia 43 tahun 27,1 hari, dan pada wanita usia 55 tahun 51,9 hari. Jadi sebenarnya panjang siklus haid 28 hari tidak sering dijumpai. Panjang siklus haid yang biasa pada manusia ialah 25-32 hari, dan kira-kira 97\% wanita yang berovulasi, siklus haidnya berkisar antara 18-42 hari. Jika siklusnya kurang dari 18 hari atau lebih dari 42 hari dan tidak teratur, biasanya siklusnya anovulatoar (Wiknjosastro, 2005). Selanjutnya bila melihat fenomena yang terjadi dalam kehidupan wanita sendiri, tidak jarang ditemukan adanya gangguan pada siklus menstruasinya.

Berdasarkan data awal dari penelitian bulan Maret 2009 pada Mahasiswi Prodi DIII Kebidanan Tingkat 1 STIKES YARSIS dari 60 responden terdapat 10 mahasiswi $(16,7 \%)$ yang tidak mengalami gangguan siklus menstruasi dan sisanya 50 mahasiswi $(83,3 \%)$ mengalami ketidakteraturan siklus menstruasi.

Ada tiga jenis gangguan siklus menstruasi, yang dikenal dalam ilmu kandungan, pertama adalah poliminorea, yaitu siklus menstruasi yang lebih pendek dari menstruasi normal (kurang dari 21 hari). Kedua oligominorea adalah gangguan siklus yang lebih panjang dari normal biasanya berlangsung lebih dari 35 hari. Ketiga adalah amenorrhea merupakan gangguan siklus menstruasi yang ditandai oleh tidak adanya menstruasi selama tiga bulan berturut-turut (Sarwono 2007). Beberapa teori menyebutkan bahwa biasanya menstruasi terjadi dengan selang waktu 22-35 hari (dihitung dari hari pertama keluarnya darah menstruasi hingga hari pertama berikutnya), (Derek, 2007).

Faktor yang mempengaruhi gangguan siklus menstruasi antara lain yaitu dari faktor internal yang berupa gangguan hormonal yaitu hormon-hormon pengendali siklus menstruasi (hipotalamuspituitari-ovarian axis) terganggu, infeksi dan keganasan serta penyakit-penyakit umum seperti : gangguan gizi, obesitas, TBC. Serta faktor psikosis, anoreksi nervosa dan stres psikologi atau syok emosional dan dari faktor eksternal yang berupa penggunaan alat kontrasepsi hormonal seperti pil, implant dan suntik (Hembing, 2006).

Stres dapat menghambat pelepasan sel telur dari ovarium sehingga terjadi penumpukan sel telur pada ovarium, yang menimbulkan penyakit ovarium polikistika. Jika mengalami penyakit ini maka darah haid yang keluar hanya berupa peluruhan dinding dalam rahim (endometrium), tidak disertai sel telur yang telah matang. Faktor-faktor tersebut, faktor stres merupakan faktor terpenting penyebab ketidakteraturan siklus menstruasi.

Penanganan untuk mengurangi dampak stres mencakup antara lain: (1) apabila stresor memiliki komponen 
psikologi, maka seseorang didorong untuk membicarakan kekhawatiran mereka dengan teman, keluarga atau ahli terapi, (2) apabila stresornya adalah fisik, perlu dilakukan intervensi untuk mengurangi nyeri, infeksi atau trauma, (3) untuk stresor fisik atau psikologi, tehnik-tehnik relaksasi, biofeedback dan visualisasi dapat menolong seseorang untuk mengurangi dampak stres pada kehidupannya, olah raga teratur juga dapat mengurangi stres (Corwin, 2001).

Dari latar belakang diatas, maka penulis tertarik mengambil masalah penelitian hubungan antara tingkat stres dengan ketidakteraturan siklus menstruasi pada mahasiswi STIKES YARSIS.

\section{METODE}

Jenis penelitian analitik dengan pendekatan cross sectional. Populasi dari penelitian ini adalah mahasiswi STIKES YARSIS sebesar 207 orang dengan besar sampel 185 orang dengan simple random sampling. Variabel independen adalah tingkat stres dan variabel dependen adalah siklus menstruasi, pengambilan data dengan kuesioner. Analisis data dengan menggunakan uji chi square dengan tingkat kemaknaan 0,05 .

\section{HASIL DAN PEMBAHASAN \\ Data Umum}

Responden dalam penelitian ini sebesar 185 mahasiswi STIKES YARSIS.

Tabel 5.1 Distribusi responden menurut klasifikasi umur pada mahasiswi di STIKES YARSIS

\begin{tabular}{cccc}
\hline No & Umur & Frekuensi & Presentase \\
\hline 1. & $18 \mathrm{Thn}$ & 19 & 10,3 \\
2. & $19 \mathrm{Thn}$ & 70 & 37,8 \\
3. & $20 \mathrm{Thn}$ & 73 & 39,5 \\
4. & $21 \mathrm{Thn}$ & 17 & 9,2 \\
5. & $22 \mathrm{Thn}$ & 6 & 3,2 \\
\hline \multicolumn{2}{c}{ Jumlah } & 185 & 100 \\
\hline
\end{tabular}

Sumber : Rekapitulasi data kuesioner bulan Oktober 2009

Menurut tabel 5.1 menunjukkan bahwa dari 185 responden yang memiliki frekuensi tertinggi adalah responden yang berumur 20 tahun yaitu $73 \quad(39,5 \%)$ responden.

Tabel 5.2 Distribusi responden menurut klasifikasi berat badan ideal pada mahasiswi STIKES YARSIS

\begin{tabular}{cccc}
\hline No. & $\begin{array}{c}\text { Berat } \\
\text { badan }\end{array}$ & Frekuensi & Presentase \\
\hline 1. & Kurus & 44 & 23,7 \\
2. & Ideal & 110 & 59,46 \\
3. & Gemuk & 31 & 16,76 \\
\hline & Jumlah & 185 & 100
\end{tabular}

Sumber : Rekapitulasi data kuesioner bulan Oktober 2009

Berdasarkan tabel 5.2 dari 185 responden frekuensi tertinggi adalah memiliki berat badan ideal dengan jumlah $110(59,46 \%)$.

Tabel 5.3 Distribusi responden menurut tingkat stres pada mahasiswi STIKES YARSIS

\begin{tabular}{lccc}
\hline No. & $\begin{array}{c}\text { Tingkat } \\
\text { stres }\end{array}$ & Frekuensi & Presentase \\
\hline 1. & Ringan & 12 & $6,5 \%$ \\
2. & Sedang & 109 & $58,9 \%$ \\
3. & Berat & 64 & $34,6 \%$ \\
\hline & Jumlah & 185 & $100 \%$ \\
\hline
\end{tabular}

Sumber : Rekapitulasi data kuesioner bulan Oktober 2009

Berdasarkan tabel 5.3 dari 185 responden frekuensi yang tertinggi adalah responden yang mengalami tingkat stres sedang yaitu $109(58,91 \%)$.

Tabel 5.4 Distribusi responden menurut siklus menstruasi pada mahasiswi STIKES YARSIS

\begin{tabular}{lccc}
\hline No. & $\begin{array}{c}\text { Siklus } \\
\text { menstruasi }\end{array}$ & Frekuensi & Presentase \\
\hline 1. & Memanjang & 26 & $13,51 \%$ \\
2. & Memendek & 47 & $24,86 \%$ \\
3. & Normal & 114 & $61,62 \%$ \\
\hline & Jumlah & 185 & $100 \%$ \\
\hline
\end{tabular}

Sumber : Rekapitulasi data kuesioner bulan Oktober 2009 
Berdasarkan tabel 5.4 diketahui dari 185 responden frekuensi tertinggi yaitu responden yang memiliki siklus menstruasi normal sebanyak 144 $(61,62 \%)$ responden.

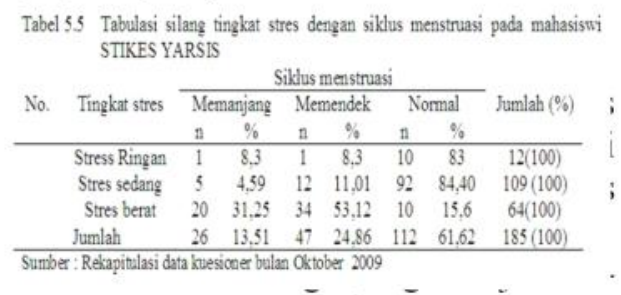

Square didapatkan $\chi^{2}$ hitung $=58,5$ dengan nilai $\chi^{2}$ tabel $=5,99$, bahwa $\chi^{2}$ hitung $>\chi^{2}$ tabel maka $\mathrm{H}_{0}$ ditolak dan $\mathrm{H}_{1}$ diterima yang berarti ada hubungan antara tingkat stres dengan siklus menstruasi pada mahasiswi STIKES YARSIS.

\section{PEMBAHASAN \\ Tingkat stres}

Berdasarkan hasil penelitian dari 185 responden sebagian besar responden mengalami tingkatan stres yang sedang sejumlah 109 orang. Hal ini dikarenakan sebagian besar responden berasal dari tingkat I dan II dimana beban psikologis dan beban mata kuliah lebih ringan dibandingkan dengan mahasiswa tingkat III.

Stres yang ringan biasanya berdampak positif karena mengakibatkan seseorang termotivasi untuk menyelesaikan masalah yang dihadapi. Sehingga tidak akan mengalami suatu masalah. Sedangkan stress sedang dan berat akan terjadi suatu permasalahan bila dihadapi oleh seorang mahasiswa. Respon stress yang dialami oleh seseorang akan memberikan respon yang berbeda walaupun mempunyai tingkatan stress yang sama. Stres yang memiliki tingkatan berat berespon negatif dan deskutif (bersifat merusak).

\section{Siklus menstruasi}

Berdasarkan hasil penelitian dari

185 responden sebagian besar responden mempunyai siklus menstruasi yang normal sejumlah 114 responden. Hal ini sesuai dengan sumber media sehat.com bahwa perubahan siklus haid pada wanita biasanya baru akan terjadi pada saat wanita menginjak usia 35 tahun. Namun perubahan ini tergantung pada asupan gizi dan kebugaran tubuh yang dimiliki individu wanita itu sendiri. Namun jika dibawah usia 35 tahun sudah mengalami perubahan siklus menstruasi hal ini bisa disebabkan oleh penyakit psikosomatis atau penyakit yang disebabkan oleh gangguan kondisi psikis.

\section{Hubungan antara tingkat stres dengan siklus menstruasi}

Tabulasi silang dengan uji ChiSquare didapatkan $\chi^{2}$ hitung $=58,5$ dengan nilai $\chi^{2}$ tabel $=5,99$, bahwa $\chi^{2}$ hitung $>\chi^{2}$ tabel maka $\mathrm{H}_{0}$ ditolak dan $\mathrm{H}_{1}$ diterima yang berarti ada hubungan antara tingkat stres dengan siklus menstruasi pada mahasiswi STIKES YARSIS. Hasil penelitian menunjukkan ada hubungan antara tingkat stres dengan menstruasi.

Tingkat stres adalah tingkatan keadaan dimana beban yang dirasakan seseorang tidak sepadan dengan kemampuan untuk mengatasi beban itu. Selain itu tingkatan stres yang dialami setiap manusia berbeda-beda yaitu stres ringan, stress sedang dan stres berat. Faktor-faktor stres yang dialami setiap orang juga berbeda, sehingga cara penanganan stres harus disesuaikan dengan faktor penyebabnya). Dampak dari stres itu sendiri ada yang berdampak positif dan negatif. Salah satu contoh stres yang memiliki dampak positif adalah seorang yang mengalami stres ringan dan sedang sebagian besar bersifat membangun dan memotivasi seseorang untuk segera menyelesaikan masalah yang bisa membuat stres. Sedangkan stres berat yaitu stres yang berdampak negatif dan bersifat merusak yang bisa membuat individu dalam keadaan sakit sampai dengan kematian. 
Keadaan stres erat sekali hubungannya dalam mempengaruhi keadaan fisik seseorang salah satunya adalah siklus menstruasi pada wanita dengan usia diatas 35 tahun. Dari hasil penelitian telah didapatkan bahwa frekuensi tertinggi adalah usia 20 tahun. Selain usia, berat badan juga bisa mempengaruhi siklus menstruasi, berat badan yang dimaksud adalah obesitas karena obesitas bisa mempengaruhi sistem metabolisme tubuh yang mengakibatkan hormon estrogen meningkat dan berpengaruh pada perubahan siklus menstruasi. Dari hasil penelitian juga didapatkan frekuensi tertinggi responden memiliki berat badan ideal sehingga frekuensi tertinggi siklus menstruasi adalah siklus normal.

Stres dapat mempengaruhi siklus menstruasi dikarenakan stres dapat menghambat pelepasan sel telur dari ovarium sehingga terjadi penumpukkan sel telur pada ovarium yang menimbulkan penyakit ovarium polikistik. Jika mengalami penyakit ini, maka darah haid yang keluar hanya berupa peluruhan dinding dalam rahim (endometrium), tidak disertai oleh meluruhnya sel telur yang telah matang. Stres ringan juga bisa mempengaruhi siklus menstruasi karena setiap individu merespon reaksi stres dengan cara berbeda-beda. Beberapa contoh reaksi yang ditimbulkan karena stres adalah susah tidur, gelisah, sedih, marah, nafsu makan menurun atau naik, pusing, bingung. Sebagian besar stres yang bisa mempengaruhi siklus menstruasi adalah tingkat stres yang berat.

Stres dapat mengganggu system metabolisme tubuh, sehingga metabolisme terganggu dan siklus haid juga ikut terganggu. Seseorang yang mengalami stres berat sering terjadi gangguan siklus menstruasi karena stres yang berat dapat meningkatkan hormon kortisol yang dapat mengganggu produksi hormon reproduksi, oleh karena itu cara penanganan stres harus tepat dan sesuai dengan factor penyebab stres itu terjadi. Stres yang sering dijumpai pada wanita yang mengalami stres berat adalah stres psikis misalnya kematian seseorang yang disayangi. Hal ini dikarenakan stres menyebabkan orang berfikir terlalu berat dan bias mempengaruhi kerja otak, sehingga berpengaruh juga pada perintah produksi hormon yang ada diotak.

Dapat disimpulkan bahwa perlunya menjaga kestabilan psikis dan fisik untuk menghindari stres yang bisa membuat siklus menstruasi tidak normal yaitu memanjang ataupun memendek.

\section{SIMPULAN}

Sebagian besar tingkat stres yang dialami responden (mahasiswa STKES YARSIS) adalah tingkat stres sedang.

Sebagian besar responden (mahasiswa STIKES YARSIS) mengalami siklus menstruasi normal.

Ada hubungan antara tingkat stress dengan siklus menstruasi pada responden (mahasiswa STIKES YARSIS).

\section{DAFTAR RUJUKAN}

Antonius S. 2008. Trauma Stres dan Duka Cita. http://frams.zai.web.id/? $p=79$. Diakses tanggal 6 Juni 2008

Bram, Wiebe. 2007. 100 Pertanyaan Mengenai Haid. Jakarta: Pustaka Sinar Harapan.

Corwin, Elizabeth. 2001. Buku Saku Patofisiologi. Jakarta: EGC.

Derek, M (2007). Proses Menstruasi dan masalah yang mangganggu. Edisi 3, Jakarta, EGC

Hanafi, Hartanto. 2004. Keluarga Berencana dan Kontrasepsi. Jakarta: Pustaka Sinar Harapan.

Hestiantoro, A. 2007. Haid Tidak Teratur Kehamilan Sulit Didapat. 
www.ringasta.multiply.com.

Diakses tanggal 17 maret 2008.

Kartini. 2007. Cantik Alami. www.mediasehat.com. Diakses tanggal 24 Maret 2008.

Llewellyn, D., Jones. 2001. DasarDasar Obstetri Dan Ginekologi. Jakarta: Hipokrates.

Notoatmodjo, S. 2003. Pendidikan dan Perilaku Kesehatan. Jakarta: Rineka Cipta.

Notoatmodjo, S. 2005. Metodologi Penelitian Kesehatan. Jakarta: Rineka Cipta.

Nursalam. 2003. Konsep dan Penerapan Metodologi Penelitian Ilmu Keperawatan. Jakarta: Salemba Medika.

Prasetyaningtyas, Deasylawati. 2007. Tetap Happy Saat Menstruasi. Surakarta: Afra Publishing Kelompok Penerbit Indiva Media Kreasi.

Sarwono, (2006). Siklus Menstruasi. Jakarta: PT. Raja Grafindo Persada.

Suliswati. 2005. Konsep Dasar Keperawatan Kesehatan Jiwa. Jakarta: EGC.

Widyasari, P. 2008. Rumah Belajar Psikologis-Stress Kerja. www.rumahbelajarpsikologi.com. Diakses tanggal 24 Maret 2008.

Wiknjosastro, Hanifa. 2005. Ilmu Kebidanan. Jakarta: Yayasan Bina Pustaka Sarwono Prawirohadjo

Winkjosastro, Hanifa. 2007. Ilmu Kandungan. Jakarta: Yayasan
Bina Pustaka Sarwono

Prawirohadjo. 